УДК 342.9

DOI https://doi.org/10.32849/2663-5313/2020.2.33

Ольга Драчевська, здобувач

Науково-дослідного інституту публічного права

\title{
ДО ПИТАННЯ ВИЗНАЧЕННЯ ПОНЯТТЯ «БАНКІВСЬКА ДІЯЛЬНІСТЬ»
}

Стаття присвячена аналізу наукових підходів до трактування поняття «банківська діяльність». Аналіз наукової літератури з різних галузей дає змогу зробити висновок про те, що науковиі неоднозначно тлумачать термін «банківська діяльність». Одні розглядають ией термін як сукупність правових дій, інші - як особливий вид господарської діяльності; як систему діючих спеціальних суб'єктів та операцій чи сукупність банківських операчій та наданих банківських послуг спещіальними суб'єктами (банками); як визначене законодавчими актами України право банків та кредитних установ реалізувати статутні функиї̈ та повноваження. Досить часто поняття «банківська діяльність» визначається за допомогою іншого поняття - «ринок банківських послуг», яке охоплюється змістом більш загального поняття «ринок фінансових послуг». Вітчизняний законодавець із поняттям «банківська діяльність» ототожнює частину операчій, здійснюваних банківськими установами. Даної конщепиї дотримується $і$ частина вітчизняних вчених у своїх наукових прачях. Встановлено, що визначення банківської діяльності, яке міститься у Законі України «Про банки і банківську діяльність», варто розглядати ширше. Законодавче визначення є дещо звуженим, оскільки містить лише перелік трвох так званих класичних видів послуг, що можуть надавати банківські установи своїм клієнтам, а саме залучення у вклади грошових коштів фізичних і юридичних осіб та розміщення зазначених коштів від свого імені, на власних умовах та на власний ризик, відкриття і ведення банківських рахунків фізичних та юридичних осіб. Аналіз доктринальних підходів до визначення банківської діяльності дав змогу автору підтримати позицію науковщів, які вважають, що банківську діяльність не можна розглядати лише через фокус здійснюваних банком операщій на фінансовому ринку. Детальний аналіз різних наукових підходів до трактування поняття «банківська діяльність» та визначення, наведеного в Законі України «Про банки і банківську діяльність», дав змогу сформулювати авторське визначення досліджуваного терміна.

Ключові слова: банківська сфера, банк, банківські послуги, підприємницька діяльність банку, банківська система.

Постановка проблеми. Ефективна банківська діяльність $є$ запорукою розвитку ринкової економіки. В умовах євроінтеграційних та глобалізаційних процесів сфера банківської діяльності зазнає змін, що позначається на формуванні понятійно-категоріального апарату.

Серед науковців відсутня єдина думка щодо трактування банківської діяльності, одні зосереджують увагу на суб'єктному складі, інші - на об'єктному; треті вважають, що банківську діяльність необхідно визначати виходячи із визначення меж тієі сфери соціально-економічного життя чи тих суспільних відносин, регулювання яких повинне здійснюватися самим банківським правом; четверті акцентують увагу на діях у межах діяльності [1, с. 72].

Відсутність єдиної думки щодо трактування банківської діяльності зумовлюе необхідність подальшого вивчення поняття та особливостей банківської діяльності.
Аналіз останніх досліджень. Питанню визначення поняття «банківська діяльність» присвячені роботи багатьох вчених, серед них: Т. А. Латковська, О. М. Олійник, О. П. Орлюк, С. Л. Глуговська, Н. Г. Нагайчук, I. А. Безклубий, Т. В. Чернадчук, С. В. Надобко. А. А. Коваленко та ін.

Метою даної статті $€$ формулювання власного визначення поняття банківської діяльності на основі проаналізованих наукових праць та чинних нормативно-правових актів.

Виклад основного матеріалу. Дослідники вказують, що категорія «діяльність» розкривається насамперед через термін «дії», тому банківська діяльність із правової точки зору може розглядатися через сукупність правових дій, що здійснюється певними суб'єктами [2, с. 26].

В економічній літературі банківську діяльність прийнято визначати через еко- 
номічні функції, що здійснюються банком [3, с. 12-30] i розглядають це поняття як вид економічної діяльності, яка стимулюе та забезпечує рух грошей в обігу, і банки в умовах ринкових відносин можуть дуже сильно впливати на економічні процеси як позитивно, так і негативно [4, с. 28].

Відповідно до Банківської енциклопедії банківську діяльність слід розглядати як сукупність правових дій, що здійснюються певними суб'єктами у формі, яка вимагається законом або договором [5].

Деякі автори вважають, що визначати банківську діяльність необхідно виходячи з визначення меж тієї сфери соціально-економічного життя чи тих суспільних відносин, регулювання яких повинне здійснюватися самим банківським правом. До банківської діяльності пропонується відносити і конструювання банківської системи, а оскільки банківська система включає в себе певні структурні елементи, то необхідно узгоджувати взаємодію всіх її елементів. Тоді банківську діяльність можна визначити як систему правових дій спеціальних суб'єктів як учасників єдиної банківської системи [6].

Банківську діяльність науковці пропонують розглядати як:

- особливий вид господарської діяльності, що систематично здійснюється спеціальними суб'єктами (банками) на підставі ліцензії (дозволу) НБУ, спрямовану на здійснення банківських операцій та надання банківських послуг, функціонування та розвиток банківської системи, реалізацію грошово-кредитної політики держави. Банківська діяльність є особливою, оскільки вона не припускає можливості об'єднання їі 3 іншими видами господарської діяльності [2, c. 91, 92];

- особливий вид систематичної господарської діяльності, що підлягає ліцензуванню, здійснюється спеціальними суб'єктами (банками) шляхом проведення банківських операцій і надання банківських послуг із метою одержання прибутку і спрямована на функціонування та розвиток банківської системи й реалізацію грошово-кредитної політики держави [7, с. 102];

- підлягаюча ліцензуванню Національним банком України сукупність банківських операцій та наданих банківських послуг спеціальними суб'єктами (банками), здійснюваних систематично, спрямованих на функціонування та розвиток банківської системи, реалізацію грошово-кредитної політики держави [8];

- систематичне здійснення кредитними організаціями з метою отримання прибутку банківських операцій, перелік яких закрі- плений законодавством [9, с. 11]. Наведене визначення виключає можливість центрального банку держави здійснювати банківську діяльність, оскільки метою його діяльності не є отримання прибутку;

- широкий спектр відносин, що передбачають і визначають фінансово-економічну спроможність і потенціал держави [10, с. 21];

- систематичну підприємницьку діяльність, здійснення якої передбачає вчинення банківських правочинів та операцій [11, с. 65]. Пропонуючи таке визначення, професор I. А. Безклубий також формулюе визначення поняття «ліцензована банківська діяльність» (підприємницька діяльність банку на підставі ліцензії НБУ з надання фінансових послуг фізичним та юридичним особам шляхом залучення грошових коштів та їх розміщення, а також здійснення розрахункових операцій, операцій з цінними паперами і валютними цінностями та інших банківських операцій 3 метою отримання прибутку) і «неліцензована банківська діяльність» (підприємницька діяльність банку 3 надання відплатних фінансових та інших послуг фізичним та юридичним особам, що не передбачає здійснення банківських операцій) [11, с. 66];

- сукупність базових (виключних) та/або окремо взятих небазових (додаткових, допоміжних тощо) банківських операцій і правочинів, які спрямовані на отримання прибутку і здійснюються банками та іншими кредитно-фінансовими установами і які становлять виключні правоздатність та вид діяльності вказаних суб'єктів господарювання, 3 приводу грошей, цінних паперів, валютних цінностей та інших фінансових інструментів як засобів платежу, заощадження і товару [12, c. 7];

- підприємницьку діяльність, яка здійснюється на власний розсуд і ризик з метою отримання прибутку; як діяльність банків як самостійних суб'єктів господарювання; як владно-організаційну діяльність НБУ $[13$, c. 62$]$.

На думку окремих учених, банківська діяльність - визначене законодавчими актами України право банків та кредитних установ реалізувати статутні функції та повноваження, здійснювати банківські операції в інтересах юридичних та фізичних осіб, надавати їм на підставі отриманих ліцензій банківські послуги, а також здійснювати в межах наданої компетенції іншу дозволену діяльність від свого імені та за власний рахунок [14, с. 53].

О. П. Орлюк визначає, що банківська діяльність - це система діючих спеціальних суб'єктів та операцій, здійснюваних ними 
як учасниками єдиної банківської системи 3 приводу грошей, цінних паперів і валютних цінностей як засобів платежу, заощадження й товару. Отже, таке визначення характеризує банківську діяльність в найширшому розумінні $[15$, с. 4$]$.

В. С. Симов'ян зазначає, що у правовому значенні банківську діяльність варто трактувати як сукупність дій, що регламентуються фінансово-правовими нормами щодо банківських операцій, діяльності щодо створення та функціонування банків та інших фінансових установ, які є елементами банківської і фінансової системи 3 метою стабільної і організованої фінансової діяльності держави [16, с. 24].

О. М. Олейник характеризує банківську діяльність як сукупність постійно або систематично здійснюваних з приводу грошей та інших фінансових інструментів операцій різних видів, об'єднаних загальною метою [17, c. 27-28]

Досить часто поняття «банківська діяльність» визначається за допомогою іншого поняття - «ринок банківських послуг», яке охоплюється змістом більш загального поняття «ринок фінансових послуг». Взагалі, ринок банківських послуг - це сфера підприємницької діяльності з приводу грошових відносин, об'єктом яких є послуги, що надаються банками фізичним та юридичним особам. Саме на ринку банківських послуг здійснюється відповідна професійна діяльність банківських установ [11, с. 64].

Згідно зі ст. 2 Закону України «Про банки і банківську діяльність» банківська діяльність - це залучення у вклади грошових коштів фізичних і юридичних осіб та розміщення зазначених коштів від свого імені, на власних умовах та на власний ризик, відкриття і ведення банківських рахунків фізичних та юридичних осіб [19].

Вітчизняний законодавець ототожнює частину операцій, здійснюваних банківськими установами, із поняттям «банківська діяльність». Даної концепції дотримується і частина вітчизняних вчених у своїх наукових працях: зокрема, банківську діяльність визначають як сукупність операцій, яку здійснює банк, А. М. Герасимович, О. В. Васюренко, О. В. Дзюблюк.

На аргументовану думку професора I. А. Безклубого, наведене законодавче визначення є дещо звуженим, оскільки містить лише перелік трьох так званих класичних видів послуг, що можуть надавати банківські установи своїм клієнтам. Проте без отримання банківської ліцензії не дозволяється здійснювати одночасно діяльність із залучення вкладів та інших коштів, що підлягають поверненню, і надання кредитів, а також ведення рахунків. Відповідна діяльність може здійснюватися банком за умов дотримання ним встановлених законодавством спеціальних економічних нормативів (наприклад, обов'язкове формування мінімального статутного капіталу та резервного фонду, нормативи ліквідності) та застережень (наприклад, збереження банківської таємниці, здійснення фінансового моніторингу), наявності фахового персоналу, технічних засобів, створення інфраструктури (наприклад, організація філій, відділень, центрів), постійного розширення та зростання якості банківських послуг [11, с. 65].

Як зазначають науковці, поняття банківської діяльності не вичерпується лише переліком окремих банківських операцій, як зазначено у визначенні, наданому у ст. 2 Закону України «Про банки і банківську діяльність». Тому в юридичній літературі науковці критикують наведене визначення та пропонують власні визначення, які, на їхню думку, повніше розкривають зміст банківської діяльності. Запропоноване нормативне визначення категорії «банківська діяльність» фактично зводить їі зміст лише до трьох банківських операцій, які банки мають право здійснювати на підставі банківської ліцензії. Але зміст цієї категоpiї набагато ширший, оскільки: по-перше, надаючи клієнтам банківські послуги, банки здійснюють значно більшу кількість операцій, перелік яких наведений у ст. 47 Закону України «Про банки і банківську діяльність»; по-друге, здійснюючи власну діяльність, банки не лише вступають у приватноправові відносини 3 клієнтами, а й стають учасниками широкого кола правовідносин, що виникають у процесі державного регулювання банківської діяльності та регулюються імперативним методом [20, с. 305].

3 наведеного в Законі України «Про банки і банківську діяльність» визначення випливає, що об'єктом банківської діяльності є грошові цінності, які можуть виконувати функції засобу платежу та нагромадження. Однак, досліджуючи практичні аспекти банківської діяльності, можна говорити й про інші цінності, з якими банк проводить операції, що також можуть виконувати вищезазначені функції. Ними можуть бути цінні папери, які мають грошове вираження, і валютні цінності. Тобто банківська діяльність - це сукупність дій банківської системи 3 приводу обороту грошей, цінних паперів і валютних цінностей як засобів платежу, збереження і як товару [21].

Відповідно до Закону «Про банки і банківську діяльність», банк, крім надання 
фінансових послуг, має право проводити також діяльність: щодо інвестицій; випуску власних цінних паперів; випуску, розповсюдження та проведення лотерей; зберігання цінностей або надання в майновий найм (оренду) індивідуального банківського сейфа; інкасації коштів і перевезення валютних цінностей; ведення реєстрів власників іменних цінних паперів (крім власних акцій); надання консультаційних та інформаційних послуг щодо банківських та інших фінансових послуг. Це дає підстави зробити висновок, що банківську діяльність не можна розглядати лише через фокус здійснюваних банком операцій на фінансовому ринку, оскільки однією з особливостей банківської діяльності є побудова скелета банківської системи і налаштування взаємодії їі складників [7]. Як підтвердження цьому С. О. Рекіянов зазначає, що банківська діяльність - це система діючих спеціальних суб'єктів та операцій, здійснюваних ними як учасниками єдиної банківської системи 3 приводу грошей, цінних паперів і валютних цінностей як засобів платежу, заощадження й товару [22].

\section{Висновки}

Ми підтримуємо позицію науковців, які вважають, що поняття «банківська діяльність» варто розглядати ширше, ніж те, що зазначено в Законі України «Про банки і банківську діяльність».

Під банківською діяльністю ми пропонуємо розуміти врегульовану правовими нормами діяльність юридичних осіб щодо надання визначених законодавством банківських послуг на підставі дозвільних документів (банківської ліцензіі) та закону.

\section{Список використаних джерел:}

1. Халімон Т.М. Принципи (засади) організації та здійснення банківської діяльності. Прикарпатський юридичний вісник. 2018. Випуск 4(25). Том 3. С. 71-75.

2. Латковська Т.А. Фінансово-правове регулювання організації та функціонування банківської системи в Україні та зарубіжних країнах: порівняльно-правовий аналіз : дис... д-ра юрид. наук: 12.00.07. Одеса, 2007. 543 с

3. Жарковская Е., Арендс И. Банковское дело : курс лекций. Москва : ИКФ Омега-Л, 2002. 399 c.

4. Глуговська С.Л. Адміністративно-правове регулювання банківської діяльності в Україні : автореф. дис. ... канд. юрид. наук : 12.00.07. Ірпінь 2014. 20 c.

5. Банківська енциклопедія / за ред. А. М. Мороза. Київ : Ельтон, 1993. 336 с.

6. Банківське право: українське і європейське : навчальний посібник / П.Д. Біленчук О. Г. Диннік, І. О. Лютий, О. В. Скороход : за заг. ред. П.Д. Біленчука. Київ : Атіка, 1999. 400 с.

7. Нагайчук Н.Г. Уточнення змісту банківської діяльності: риси і принципи. Вісник університету банківської справи Національного банку України. 2014. № 3 (21). С. 98-103.

8. Латковська Т. А. Банківська діяльність як предмет регулювання різних галузей права. Акту альні проблеми держави і права : збірник наукових праць. 2009. Випуск 49. С. 343.

9. Филатов Ю.В. Правовое положение банка как субъекта гражданского права : дисс. ... канд. юрид. наук: 12.00.14. Екатеринбург, 1999. 219 с.

10. Заверуха І.Б. Банківське право : посібник для студентів. Львів : Астролябія, 2002. 222 с.

11. Безклубий I.A. Теоретичні проблеми банківських правочинів : дис.. ... докт. юрид. наук 12.00.03. Київ, 2006. 486 с.

12. Дроздова Н.В. Договір про надання фінансових послуг у цивільному праві України : автореф. дис. ... канд. юрид. наук. Київ, 2005. 22 с.

13. Ортинський В. Л. Основи держави і права України. 2-ге вид., допов. і переробл. Львів : Оріяна-Нова, 2005. 368 с.

14.Банківське право України : навчальний посібник / А. М. Жуков, А. Ю. Іоффе, В. Л. Кротюк та ін.; за заг. ред. А. О. Селіванова. Київ : Ін Юре, 2000. 384 c.

15. Орлюк О.П. Правові проблеми організації та діяльності банківської системи України : дис. ... докт. юрид. наук : 12.00.07. Харків, 2003. 381 с.

16. Симов'ян B.C. Банківський контроль в Україні: адміністративно-правові засади : дис. ... кандидата юрид. наук : 12.00 .07 . Харків, 2011.274 с

17. Олейник О. М. Основы банковского права : курс лекций. Москва : Юристъ, 1997. С. 27-28.

18. Туляй Е.Ю. Финансово-правовое регулирование банковской деятельности в Российской Федерации. Томск : Изд-во НТЛ, 2010. 184 с.

19. Про банки і банківську діяльність Закон України від 07.12.2000 № 2121-III. URL : https://zakon.rada.gov.ua/laws/show/2121-14 (дата звернення: 12.12.2019).

20. Фінансове право України / Л. К. Воронова, М. П. Кучерявенко, Н. Ю. Пришва та ін.; за ред. Л. К. Воронової. Київ, 2009. 395 с.

21. Опря А. Т. Фінансове право : навчальний посібник. Київ : Центр навч. літератури, 2004. 248 c.

22. Рекіянов С. О. Сутність банківської системи України та їі функції в сучасних умовах. Наукові праці МАУП. 2013. Вип. 2 (37). С. 77-83. 
The article is devoted to the analysis of scientific approaches to the interpretation of the concept of "banking". The analysis of scientific literature from different fields makes it possible to conclude that scientists have ambiguously interpreted the term "banking". Some see this term as a set of rules, others as a particular type of economic activity or as a system of existing special entities and transactions, or a set of banking operations and banking services provided by special entities (banks); determined by the legislation of Ukraine the right of banks and credit institutions to exercise statutory functions and powers. Quite often, the term "banking" is defined by another term - the "banking market", which is covered by the more general concept of "financial services market". The domestic legislator with the concept of "banking" identifies some of the operations carried out by banking institutions. This concept is followed by some domestic scientists in their scientific works. It is established that the definition of banking activity contained in the Law of Ukraine "On Banks and Banking" should be considered more broadly. The legislative definition is somewhat narrow, since it contains only a list of three so-called classic types of services that can be provided by banking institutions to their clients, namely attracting deposits of individuals and legal entities and placing these funds on their own behalf, on their own terms and on their own risk, opening and maintaining bank accounts of individuals and legal entities. The analysis of doctrinal approaches to the definition of banking activity allowed the author to support the position of scholars who believe that banking activity cannot be considered solely because of the focus of the bank's operations on the financial market. A detailed analysis of the various scientific approaches to the interpretation of the concept of "banking" and the definition of the Law of Ukraine "On Banks and Banking" allowed us to formulate the author's definition of the term under study.

Key words: banking, banking, banking services, bank business, banking system. 